\title{
Pendugaan Kadar Biomassa dan Karbon Tersimpan pada Berbagai Kemiringan dan Tutupan Lahan di KHDTK Gunung Bromo UNS
}

\author{
Tira Anggit Drupadi ${ }^{*}$, Dwi Priyo Ariyanto ${ }^{2}$ dan Sudadi ${ }^{2}$ \\ ${ }^{1}$ Mahasiswa Progam Studi Agroteknologi, Fakultas Pertanian, Universitas Sebelas Maret \\ ${ }^{2}$ Fakultas Pertanian, Universitas Sebelas Maret \\ Jl. Ir. Sutami 36, Kentingan, Jebres, Surakarta, Jawa Tengah 57126 \\ *Alamat korespondensi: dp_ariyanto@staff.uns.ac.id
}

\begin{tabular}{lrc}
\hline \multicolumn{2}{c}{ INFO ARTIKEL } & ABSTRACT/ABSTRAK \\
\hline Diterima: & $19-02-2021$ & \\
Direvisi: & $19-07-2021$ & Estimation of Biomass Levels and Carbon Stock at Various Slopes and Land \\
Dipublikasi: 11-08-2021 & Cover in KHDTK Gunung Bromo UNS
\end{tabular}

Keywords:

Carbon stock, Litter, Sequestration

Kata Kunci:

Karbon tersimpan,

Sekuestrasi, Serasah
Changes in forest land cover result in reduction of biomass and carbon sequestration content in vegetation. The reduction of biomass can be influenced by the slope factor. Steep slopes are known to reduce vegetation growth and impact biomass. This study aimed to determine the effect of land cover and slope on tree biomass, litter and carbon stock as well as to determine levels of tree biomass, litter and carbon stock. This study used survey methods and purposive sampling to determine the observation points on four land covers (Mixed, Mahogany, Pine-Mahogany, Pine) and three classes of land slopes $(0-15 \%, 15-30 \%$, and $>30 \%)$. Estimation of biomass was done by a non-destructive method by using allometric formula. The plot size was $20 \mathrm{~m} \mathrm{x} 20 \mathrm{~m}$ with total of 48 plots for observation of trees $\geq 5 \mathrm{~cm}$ in diameter, then prepared subplots of $1 \mathrm{~m} \times 1 \mathrm{~m}$ for litter plot. The experimental results showed that Pine land cover produced the highest tree biomass and carbon stock compared to other land covers and that variations in slope produced uniform or the same tree biomass and carbon stock. The tree biomass and carbon content in each land cover were 171.72-385 tones/ha and 80.71-181.12 tones $\mathrm{C} / \mathrm{ha}$, respectively. Litter biomass content in each land cover ranged between 0.60 and 1,60 ton/ha/month.

Perubahan tutupan lahan hutan mengakibatkan penurunan biomassa dan sekuestrasi karbon pada vegetasi. Penurunan biomassa dapat dipengaruhi faktor kemiringan lereng. Lereng yang curam diketahui menurunkan pertumbuhan vegetasi dan berdampak pada biomassa. Penelitian ini bertujuan untuk mengetahui pengaruh tutupan dan kemiringan lahan terhadap biomassa pohon, serasah dan karbon tersimpan serta mengetahui kadar biomassa pohon, serasah dan karbon tersimpan. Penelitian ini menggunakan metode survey dan penentuan titik pengamatan secara purposive sampling pada empat tutupan (Campuran, Mahoni, Pinus-Mahoni, Pinus) dan tiga kelas kemiringan lahan (0-15\%, 15-30\%, dan >30\%). Estimasi biomassa menggunakan metode non-destructive dan dihitung menggunakan persamaan allometrik. Petak ukur dibuat berukuran $20 \mathrm{~m}$ x $20 \mathrm{~m}$ dengan jumlah 48 petak untuk pengamatan pohon dengan diameter $\geq 5 \mathrm{~cm}$, kemudian dibuat sub petak untuk pengamatan serasah berukuran $1 \mathrm{~m} \mathrm{x} 1 \mathrm{~m}$. Hasil percobaan menunjukkan bahwa tutupan lahan Pinus menghasilkan biomassa pohon dan karbon tersimpan tertinggi bila dibandingkan dengan tutupan lahan lainnya dan variasi kemiringan menghasilkan biomassa pohon 
dan karbon tersimpan yang seragam atau sama. Kadar biomassa pohon dan karbon pada setiap tutupan lahan masing-masing berkisar antara 171,72-385 ton/ha dan 80,71-181,12 tonC/ha. Kadar biomassa serasah pada setiap tutupan berkisar antara $0,60-1,60$ ton/ha/bulan.

\section{PENDAHULUAN}

Kawasan Hutan Dengan Tujuan Khusus (KHDTK) Gunung Bromo Universitas Sebelas Maret merupakan salah satu hutan produksi yang dikelola oleh Universitas Sebelas Maret dengan dominasi tutupan tanaman tahunan sehingga mampu menyimpan karbon. Hal tersebut dapat dilihat dari potensi tegakan yang didominasi tumbuhan berkayu dari berbagai jenis tutupan lahan yang berbeda. Tegakan berpotensi menyerap karbondioksida dari udara dan disimpan dalam bentuk biomassa. Perubahan tutupan lahan hutan menjadi lahan pertambangan, perkebunan, pertanian, pemukiman, maupun industri mengakibatkan penurunan biomassa dan simpanan karbon pada vegetasi.

Perubahan tutupan lahan juga berdampak pada perubahan suhu di permukaan bumi menjadi lebih panas dibanding dengan suhu normal yang diakibatkan naiknya konsentrasi gas karbondioksida $\left(\mathrm{CO}_{2}\right)$ dan gas-gas lainnya di atmosfer. Berdasarkan data per 2011, karbondioksida yang ada di bumi mengalami peningkatan sebanyak $40 \%$ sejak 50 tahun lalu. Rata-rata suhu bumi akan naik antara $0,3^{\circ} \mathrm{C}$ ke $0,7^{\circ} \mathrm{C}$ pada periode $2016-2035$ (Akbar \& Endang, 2019). Upaya untuk mengurangi pemanasan global yaitu melalui sektor kehutanan. Hutan yang terdiri dari sekumpulan pohon memiliki peran penting dalam menyerap karbondioksida dan menyimpannya dalam bentuk biomassa.

Biomassa merupakan massa dari vegetasi yang masih hidup yaitu tajuk pohon, tumbuhan bawah atau gulma, dan tanaman semusim (Hairiah \& Rahayu, 2007). Biomassa berasal dari proses fotosintesis dengan menyerap karbondioksida dari udara kemudian disimpan dalam bentuk jaringan organ tanaman seperti batang, dahan, ranting, akar, daun. Dengan demikian, besaran biomassa tegakan dapat dijadikan dasar dalam menentukan jumlah karbondioksida yang diserap dan disimpan oleh tegakan/ cadangan karbon.

Besar kecilnya biomassa bergantung pada pertumbuhan vegetasi. Kemiringan lahan diketahui berpengaruh terhadap pertumbuhan tegakan hutan. Kemiringan lahan merupakan sudut yang dibentuk oleh perbedaan tinggi permukaan lahan (relief) antara bidang datar tanah dengan bidang horizontal dan pada umumnya dihitung dalam persen. Menurut Banjarnahor dkk. (2018), penggerusan tanah oleh air pada daerah berlereng mengakibatkan tanah terkikis dan terangkut, sehingga produktivitas tanah menurun dan memengaruhi pertumbuhan vegetasi). Kemiringan diketahui memengaruhi pertumbuhan vegetasi dimana vegetasi yang tumbuh pada lereng datar (8\%) memiliki pertumbuhan yang lebih bagus dibandingkan pada kemiringan lereng 28\% dan 35\% (Khairani, 2019). Kelas kemiringan juga diketahui memengaruhi kadar serasah. Lereng yang datar memiliki kadar serasah lebih tinggi dibandingkan dengan lereng yang curam. Suryanto dan Wawan (2017) menjelaskan bahwa kemiringan 0-8\% memiliki kadar serasah (kandungan bahan organik) yang lebih tinggi dibandingkan kandungan bahan organik pada kemiringan 15-25\%. Tujuan dari penelitian ini yaitu untuk mengetahui pengaruh kemiringan dan tutupan lahan terhadap biomassa dan mengetahui kadar biomassa dan karbon tersimpan di KHDTK Gunung Bromo UNS. Data pendugaan biomassa di KHDTK Gunung Bromo selanjutnya dapat digunakan untuk menyusun strategi dalam pengurangan emisi gas rumah kaca.

\section{BAHAN DAN METODE}

Penelitian dilaksanakan pada bulan Juli 2019 sampai bulan Januari 2020. Lokasi penelitian di KHDTK Gunung Bromo UNS, Karanganyar dan Laboratorium Ekologi dan Manajemen Produksi Tanaman, Fakultas Pertanian, Universitas Sebelas Maret. Metode pengambilan data menggunakan metode survey, sedangkan penempatan petak ukur (plot) secara purposive sampling berdasarkan tutupan dan kemiringan lahan. Tutupan lahan yang digunakan yaitu tutupan lahan Campuran, Mahoni, Pinus-Mahoni, dan Pinus. Kelas kemiringan lahan yang digunakan yaitu $0-15 \%, 15-30 \%$, dan $>30 \%$. Pada setiap tutupan dan kemiringan lahan diulang sebanyak empat kali sehingga terdapat 48 petak ukur.

Pembuatan petak ukur pada tiap tutupan dan kemiringan lahan berukuran $20 \mathrm{~m}$ x $20 \mathrm{~m}$ untuk mengumpulkan data pohon yaitu jenis pohon, tinggi 
total pohon, dan diameter setinggi dada/DBH $\geq 5 \mathrm{~cm}$ (Hairiah dkk., 2011). Pembuatan litter trap (jaring perangkap serasah) berukuran $1 \mathrm{~m} \times 1 \mathrm{~m}$ dengan ketinggian $>50 \mathrm{~cm}$ di atas permukaan tanah di dalam petak ukur (plot) untuk mengumpulkan data serasah. Serasah yang tertampung pada litter trap diambil setiap 14 hari selama 3 bulan. Serasah ditimbang berat basahnya dengan memisahkan komponen daun, ranting, bunga dan buahnya. Selanjutnya, serasah dikeringkan dalam oven selama 48 jam pada suhu $80^{\circ} \mathrm{C}$ (Hairiah \& Rahayu, 2007).

Pendugaan kadar biomassa pohon dilakukan dengan menggunakan metode non-destructive (pendugaan tidak langsung). Biomassa pohon dihitung dengan menggunakan persamaan allometrik (Tabel 1).

Tabel 1. Rumus persamaan allometrik dalam pendugaan biomassa atas tanah untuk jenis pohon

\begin{tabular}{lll}
\hline \multicolumn{1}{c}{ Jenis Pohon } & \multicolumn{1}{c}{ Rumus Allometrik } & \multicolumn{1}{c}{ Sumber } \\
\hline Mahoni (Swietenia mahagony) & $\mathrm{Bt}=0,9029\left(\mathrm{D}^{2} . \mathrm{H}\right)^{0,6840}$ & Purwanto dkk., 2012 \\
Pinus (Pinus merkusii) & $\mathrm{Bt}=0,03292+\left(\mathrm{DBH}^{2}+\mathrm{H}\right)^{0,97318}$ & Miyakuni et al. $(2005)$ \\
Jati (Tectona grandis) & $\mathrm{Bt}=0,015\left(\mathrm{D}^{2} \mathrm{H}\right)^{1,084}$ & BPKH $(2009)$ \\
Sonokeling (Dalbergia latifolia) & $\mathrm{Bt}=0,7458\left(\mathrm{D}^{2} \mathrm{H}\right)^{0,6394}$ & Purwanto dkk., 2012 \\
Pohon lainnya & $\mathrm{Bt}=0,0219\left(\mathrm{D}^{2} \mathrm{H}\right)^{1,0102}$ & Scheyvens et al. $(2011)$ \\
\hline angan: Bt = Biomassa total (kg/pohon), D = Diameter Breast Height $(\mathrm{DBH}) /$ diameter setinggi dada $(\mathrm{cm}) . \mathrm{H}=$ tinggi pohon $(\mathrm{m})$.
\end{tabular}

Cadangan karbon (karbon tersimpan) dihitung dengan persamaan sebagai berikut: C Tersimpan $=$ Biomassa $\times$ 0,46 (Hairiah \& Rahayu, 2007). Sementara itu, kadar biomassa serasah dihitung dengan rumus:

Total BK $=\frac{\begin{array}{ll}\text { BK } \\ \text { contoh }\end{array}}{\begin{array}{l}\text { BB } \\ \text { contoh }\end{array}}$ sub $x$ total BB contoh

Keterangan:

$\mathrm{BK}=$ berat kering $(\mathrm{g})$

$\mathrm{BB}=$ berat basah $(\mathrm{g})$

Hasil pendugaan biomassa pohon, serasah, dan karbon tersimpan dianalisis dengan menggunakan ANOVA ketelitian 5\% dan dilakukan analisis korelasi dengan metode Pearson. Apabila terdapat pengaruh nyata dilanjutkan dengan uji DMRT pada taraf nyata 5\%.

\section{HASIL DAN PEMBAHASAN}

\section{Deskripsi Tutupan Lahan}

Kawasan Hutan Dengan Tujuan Khusus (KHDTK) Gunung Bromo UNS memiliki luas wilayah 122,58 ha dan terdapat enam jenis tutupan lahan, yaitu tutupan lahan campuran, mahoni, pinus-mahoni, pinus, lahan terbuka, dan tutupan lahan semusim (Gambar 1). Tutupan campuran dengan luas 30,24 ha terdiri dari tegakan jati, saga, laban, kedawung, jambu monyet, lamtoro, randu, mahoni, angsana, dan jenis lainnya. Jarak tanam pohon di tutupan campuran yaitu berkisar 100-400 cm. Tutupan mahoni memiliki luas wilayah 36,6 ha dengan jarak tanam $600 \mathrm{~cm}$ x $600 \mathrm{~cm}$. Luas wilayah pinus-mahoni yaitu 28,89 ha dengan presentase pohon pinus $60 \%$ dan mahoni $40 \%$. Jarak tanam pohon pinus di tutupan pinus-mahoni yaitu $400 \mathrm{~cm}$, sedangkan jarak tanam pohon pinus dan mahoni yaitu $800 \mathrm{~cm}$. Luas wilayah pinus 46,53 ha dengan jarak tanam antar pohon yaitu $400 \mathrm{~cm}$ x $400 \mathrm{~cm}$, luas wilayah lahan terbuka yaitu 2,97 ha, dan tutupan lahan semusim dengan luas 10,18 ha terdiri dari tanaman jagung, kacang tanah, singkong, dan tanaman semusim lainnya.

\section{Biomassa Pohon dan Karbon Tersimpan}

Hasil analisis sidik ragam menunjukkan bahwa tutupan lahan berpengaruh terhadap biomassa pohon dan karbon tersimpan $(\mathrm{P}<0,05)$ (Gambar 2), sedangkan kemiringan lahan tidak memberikan pengaruh terhadap biomassa pohon dan karbon tersimpan $(\mathrm{P}>0,05)$. Tutupan lahan memberikan pengaruh terhadap kadar biomassa dan karbon tersimpan diduga komposisi dan struktur tegakan dari tutupan lahan di KHDTK Gunung Bromo UNS. Banyaknya jenis tegakan pada tiap tutupan menjadi penyumbang kadar biomassa di lokasi penelitian. Kemiringan tidak memberikan pengaruh terhadap biomassa pohon dan karbon tersimpan. Hal ini diduga jarak tanam pada tiga kelas kemiringan lahan relatif sama. Menurut Refliaty dan Marpaung (2010), kemiringan lereng merupakan unsur topografi yang berpengaruh terhadap aliran permukaan dan erosi. Semakin curam lereng, erosi dan aliran permukaan yang terjadi semakin besar. Begitu juga dengan kandungan bahan organik. 
Semakin curam lereng, kandungan bahan organiknya juga semakin rendah. Namun, dengan adanya kerapatan vegetasi/jarak tanam yang relatif sama pada tiap kemiringan tersebut akan memperkecil aliran permukaan dan bahaya erosi sehingga pada lereng yang curam kandungan bahan organik dapat dipertahankan, sehingga tiap kemiringan dengan jarak tanam relatif sama memiliki kandungan bahan organik yang sama.
Demikian juga disebutkan bahwa kanopi yang lebih rapat menyebabkan bobot isi tanah pada setiap kemiringan relatif sama (Sandrawati dkk., 2016). Bobot isi tanah menurut Arsyad (2010) merupakan salah satu komponen penting yang dapat menentukan produktivitas tanah maupun tanaman sehingga bobot isi tanah pada tiap kemiringan relatif sama maka produktivitas tanaman juga relatif sama.
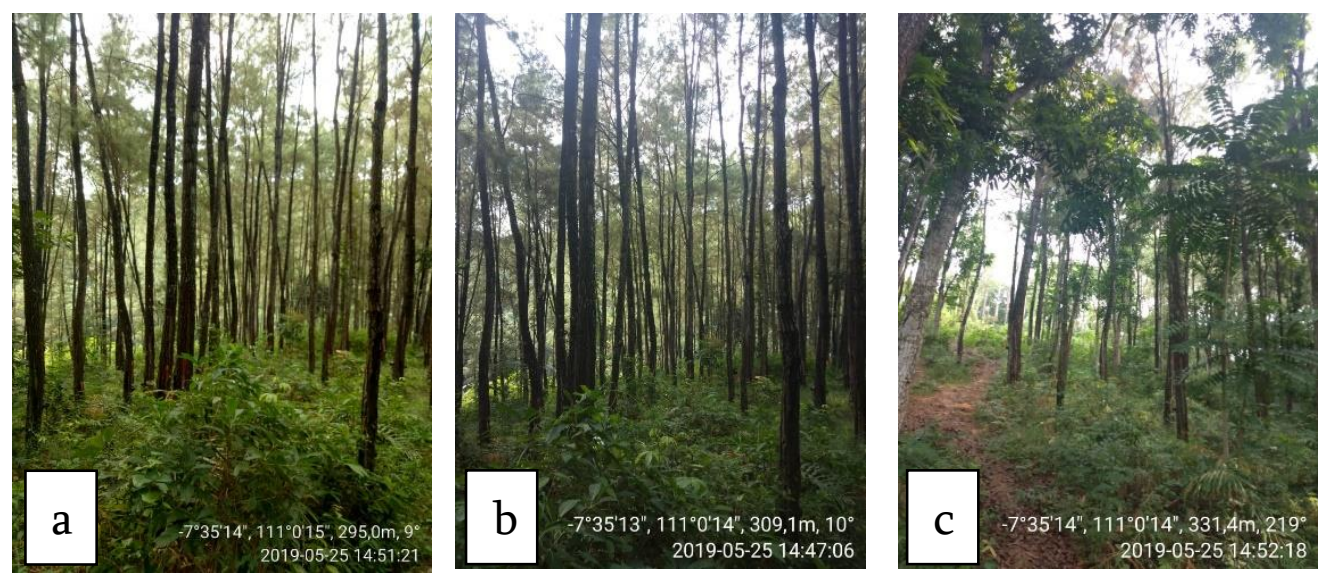

Gambar 1. Tutupan lahan di KHDTK Gunung Bromo UNS

(a) Tutupan lahan pinus kemiringan $0-15 \%$.

(b) Tutupan lahan pinus kemiringan $>30 \%$.

(c) Tutupan pinus-mahoni kemiringan $>30 \%$.

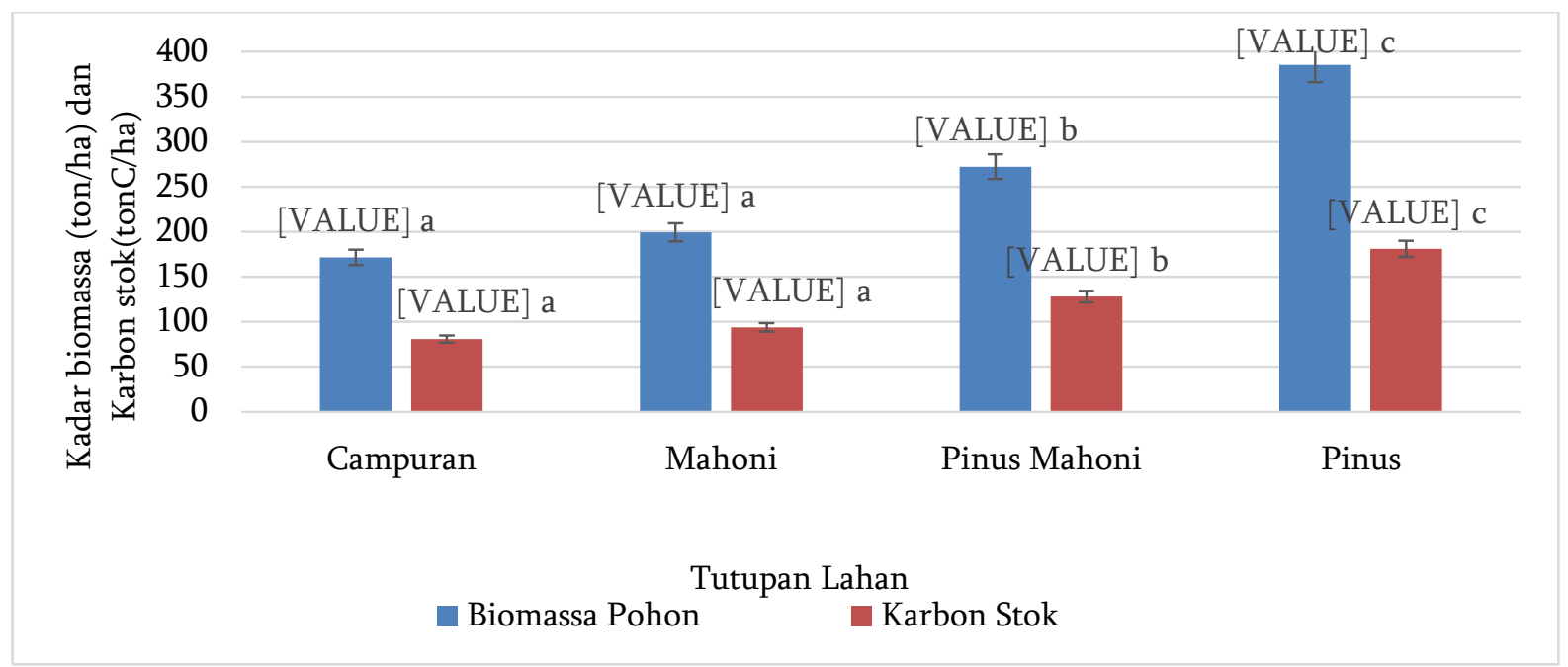

Keterangan: Antar angka yang diikuti dengan huruf yang sama tidak berbeda nyata menurut uji DMRT pada taraf nyata 5\%.

Gambar 2. Pengaruh jenis tutupan lahan terhadap biomassa pohon dan karbon tersimpan.

Biomassa pohon pada tutupan lahan tutupan lahan Pinus. Rata-rata biomassa pohon Campuran tidak berbeda nyata dengan tutupan tertinggi terdapat pada tutupan lahan Pinus sebesar lahan Mahoni. Biomassa pohon pada tutupan lahan Campuran dan Mahoni berbeda nyata dengan tutupan Pinus-Mahoni dan Pinus, sedangkan tutupan lahan Pinus-Mahoni berbeda nyata dengan 385,36 ton/ha dengan menyimpan karbon sebesar 181,12 ton $\mathrm{C} /$ ha, sedangkan rata-rata biomassa pohon terendah terdapat pada tutupan lahan Campuran sebesar 171,72 ton/ha serta menyimpan 
karbon sebesar 80,71 ton C/ha. Nilai biomassa pohon berbanding lurus dengan nilai karbon karena setiap penambahan kandungan biomassa akan diikuti oleh penambahan kandungan karbon. Menurut Hairiah dan Rahayu (2007) hal ini disebabkan nilai kandungan karbon suatu bahan organik yaitu $47 \%$ dari total biomassanya.

Tingginya nilai biomassa dan cadangan karbon pada tutupan lahan Pinus, diduga karena parameter tinggi pohon memengaruhi biomassa pohon. Hal ini sesuai dengan Bismark dkk. (2008) yang menyatakan bahwa peningkatan biomassa dan cadangan karbon (karbon tersimpan) disebabkan ukuran pohon di lokasi tersebut. Rata-rata tinggi pohon pada tutupan Pinus lebih tinggi $16,53 \mathrm{~m}$ dibandingkan tutupan lahan Campuran 14,33 m, Mahoni 15,34 m, maupun Pinus-Mahoni 14,9 m. Feldpausch et al. (2011) menyatakan hal yang sama bahwa parameter tinggi dan diamater pohon dapat meningkatkan biomassa. Sifat pohon pinus tidak terlepas dari faktor lingkungan yang mempengaruhi pertumbuhan antara lain cahaya matahari, air, suhu udara, dan kelembapan udara. Intensitas cahaya matahari yang optimal membantu dalam proses fotosintesis.

Perbedaan rata-rata biomassa pohon dan cadangan karbon pada tiap tutupan di KHDTK Gunung Bromo UNS disebabkan perbedaan jenis vegetasi. Tiap tegakan vegetasi memiliki model allometrik, sehingga kadar biomassa tiap vegetasi berbeda-beda. Hal ini memiliki kesamaan dengan penelitian yang dilakukan Purwanto dkk. (2012) yang melaporkan kandungan biomassa tegakan mahoni 23,119 ton/ha, akasia 7,036 ton/ha, dan sonokeling 3,440 ton/ha. Pebriandi dkk. (2013) juga menyatakan bahwa jumlah karbon tersimpan berbeda-beda antara tumbuhan yang satu dengan lainnya, tergantung pada jenis tumbuhan tersebut.

Berdasarkan Tabel 3, tutupan lahan Pinus dengan luas wilayah 46,53 ha memiliki kandungan biomassa sebesar 17.930,80 ton dengan karbon tersimpan 8.427,51 ton C. Luas wilayah PinusMahoni lebih kecil dibandingkan dengan tutupan lahan Campuran, namun memiliki kandungan biomassa lebih tinggi $7.869,35$ ton dibandingkan dengan Campuran 5.192,81 ton. Hal ini dikarenakan dipengaruhi oleh kerapatan tanaman pada suatu tutupan lahan. Berdasarkan penelitian Istomo dan Farida (2017), biomassa tegakan semakin meningkat dengan meningkatnya kerapatan tegakan, demikian pula karbon tersimpan juga dipengaruhi oleh kerapatan tegakan. Keseluruhan kandungan biomassa pada empat jenis tutupan lahan di KHDTK Gunung Bromo UNS yaitu 38.291,27 ton dan karbon tersimpan/simpanan karbon sebesar 17.996,85 ton C.

Tabel 3. Total kandungan biomassa di KHDTK Gunung Bromo UNS

\begin{tabular}{lccc}
\hline Jenis tutupan lahan & $\begin{array}{c}\text { Luas wilayah } \\
\text { (ha) }\end{array}$ & $\begin{array}{c}\text { Kandungan biomassa } \\
\text { (ton) }\end{array}$ & $\begin{array}{c}\text { Karbon tersimpan } \\
\text { (ton C) }\end{array}$ \\
\hline Campuran & 30,24 & $5.192,81$ & $2.440,68$ \\
Mahoni & 36,60 & $7.298,41$ & $3.430,16$ \\
Pinus-Mahoni & 28,89 & $7.869,35$ & $3.698,50$ \\
Pinus & 46,53 & $17.930,80$ & $8.427,51$ \\
\hline Total & & $38.291,37$ & $17.996,85$ \\
\hline
\end{tabular}

\section{Biomassa Serasah}

Hasil analisis sidik ragam menunjukkan bahwa tutupan lahan berpengaruh terhadap biomassa serasah $(\mathrm{P}<0,05)$ (Gambar 3$)$, sedangkan kemiringan lahan tidak memberikan pengaruh terhadap biomassa serasah $(\mathrm{P}>0,05)$. Tutupan lahan memberikan pengaruh terhadap kadar biomassa serasah diduga tajuk tiap tegakan yang menyumbang serasah yang ditampung pada litter trap. Selain itu, diduga karena faktor lingkungan (iklim) maupun kerapatan. Menurut Rositah dkk. (2013) kerapatan merupakan faktor yang memengaruhi jatuhnya serasah.
Tutupan lahan Campuran, Mahoni, dan Pinus-Mahoni di KHDTK Gunung Bromo UNS tidak berbeda nyata terhadap biomassa serasah namun pada tutupan lahan Pinus berbeda nyata rata-rata 0,60 ton/ha/bulan (Gambar 2). Biomassa serasah tertinggi pada tutupan lahan Mahoni yaitu sebesar 1,60 ton/ha/bulan, sedangkan biomassa serasah terendah pada tutupan lahan pinus sebesar 0,60 ton/ha/bulan.

Rendahnya guguran seserah pohon pinus di KHDTK Gunung Bromo UNS, disebabkan pohon pinus mendapat cahaya matahari yang cukup dan memiliki ukuran tajuk yang tidak terlalu lebar. Hal ini sesuai dengan Sallata (2013), yang menyatakan 
bahwa pohon pinus tergolong pohon yang membutuhkan cahaya matahari secara penuh (jenis heliophytes) sehingga suhu udara di tutupan lahan Pinus menjadi rendah dan kelembapan udara tinggi sehingga produktivitas serasah rendah. Perbedaan kadar biomassa serasah tiap tutupan lahan diduga bahwa jenis vegetasi dapat memengaruhi biomassa serasah. Riyanto dkk. (2013) menyatakan bahwa perbedaan jenis tumbuhan penyusun suatu tegakan memengaruhi jumlah serasah dengan sumbangan serasah tertinggi berturut-turut yaitu kakao $66 \%$, durian $27,4 \%$, kopi $23,4 \%$, karet $13,2 \%$, petai $12,1 \%$, sonokeling $11,9 \%$, dan kemiri $2,3 \%$.

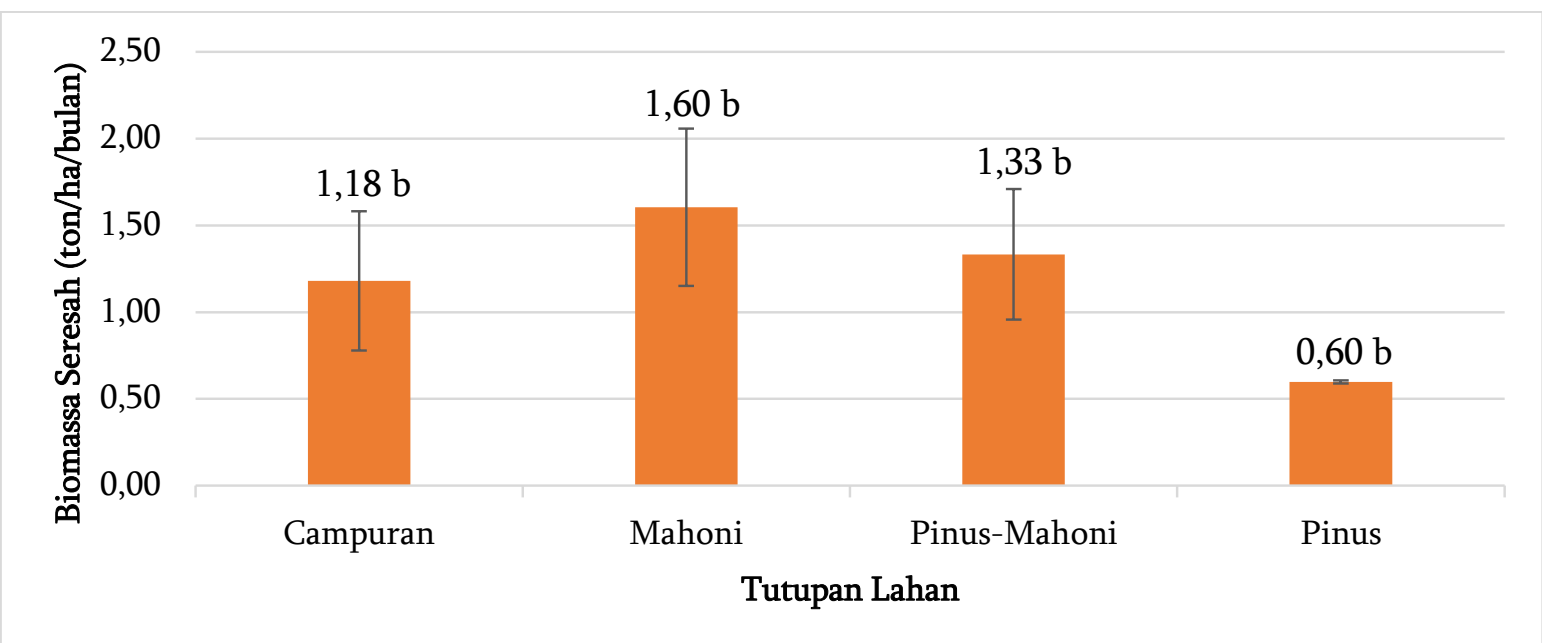

Keterangan: Antar angka yang diikuti dengan huruf yang sama tidak berbeda nyata menurut uji lanjut DMRT pada taraf nyata 5\%.

Gambar 3. Pengaruh jenis tutupan lahan terhadap biomassa serasah.

Menurut Rahajoe dan Alhamd (2013) selain jenis vegetasi, diketahui bahwa sumbangan komponen serasah dapat memengaruhi besar kecilnya biomassa serasah. Berdasarkan komposisi serasah menurut bagian-bagian tanaman, seluruh plot perlakuan didominasi oleh daun dengan ratarata 42,02 ton/ha/2 minggu atau $71 \%$. Sumbangan serasah daun lebih besar dibandingkan komponen yang lain, dikarenakan bentuk dan ukuran daun yang lebar dan tipis, sehingga mudah gugur oleh angin. Sumbangan serasah daun mendominasi diakibatkan kondisi iklim. Penelitian ini dilaksanakan pada musim kemarau, sehingga sumbangan serasah daun lebih banyak karena sebagai strategi untuk bertahan pada kondisi yang kurang air.

Rata-rata biomassa serasah pada kemiringan $0-15 \%$ yaitu 0,61 ton/ha/2 minggu, kemiringan 15 $30 \%$ yaitu 0,65 ton/ha/2 minggu, sedangkan pada kemiringan $>30 \%$ yaitu 0,51 ton/ha/2 minggu. Kemiringan lereng 0-15\%, 15-30\%, dan $>30 \%$ tidak memberikan pengaruh terhadap biomassa serasah. Hal ini diduga jarak tanam relatif sama tiap kelas kemiringan di KHDTK Gunung Bromo UNS. Menurut Mawazin dan Suhendi (2008), jarak tanam berpengaruh pada penyerapan cahaya untuk proses fotosintesis vegetasi. Semakin rapat jarak tanam, populasi vegetasi tanaman semakin banyak sehingga persaingan mendapat cahaya matahari semakin ketat.

\section{SIMPULAN}

Tutupan lahan Pinus menghasilkan biomassa pohon dan karbon tersimpan yang tertinggi bila dibandingkan pada tutupan lahan Campuran, Mahoni, dan Pinus-Mahoni, sedangkan kemiringan lereng menghasilkan biomassa pohon dan karbon tersimpan seragam atau sama. Kadar biomassa pohon dan karbon di setiap tutupan lahan yaitu 171,72385,36 ton/ha dan $80,71-181,12$ ton C/ha. Kadar biomassa serasah di setiap tutupan lahan yaitu 0,60 1,60 ton/ha/bulan.

\section{UCAPAN TERIMA KASIH}

UPT Pusat Pendidikan dan Pelatihan UNS sebagai pengelola KHDTK Gunung Bromo UNS yang telah memberikan izin dan memfasilitasi selama kegiatan penelitian berlangsung. 


\section{DAFTAR PUSTAKA}

Akbar, T, dan S Endang. 2019. Menghitung cadangan karbon yang tersimpan di Taman Purbakala Bukit Siguntang Palembang Sumatera Selatan. SYLVA. 8 (1): 21-29.

Arsyad, S. 2010. Konservasi Tanah \& Air. IPB Press. Bogor.

Banjarnahor, N, KS Hindarto, dan Fahrurrozi. 2018. Hubungan kelerengan dengan kadar air tanah, $\mathrm{pH}$ tanah, dan penampilan jeruk gerga di Kabupaten Lebong. JIPI. 20(1): 13-18.

Bismark, M, N Heriyanto, dan S Iskandar. 2008. Biomassa dan kandungan karbon pada hutan produksi di Cagar Biosfer Pulau Siberut, Sumatera Barat. Penelitian Hutan dan Konservasi Alam. 5(5): 397-407.

[BPKH] Balai Pemantapan Kawasan Hutan Wilayah XI Jawa-Madura. 2009. Alometrik Berbagai Jenis Pohon untuk Menaksir Kandungan Biomassa dDan Karbon Di Hutan Rakyat. Laporan BPKH Wilayah XI Jawa-Madura \& MFP II. Yogyakarta.

Feldpausch, TR, L Banin, OL Phillips, TR Baker, SL Lewis, CA Quesada, K Affum-Baffoe, EJMM Arets, NJ Berry, M Bird, ES Brondizio, P de Camargo, J Chave, G Djagbletey, TF Domingues, M Drescher, PM Fearnside, MB Franca, NM Fyllas, G Lopez-Gonzalez, A Hladik, N Higuchi, MOHunter, Y. Iida, KA Salim, AR Kassim, M Keller, J Kemp, DA King, J.C. Lovett, BS Marimon, BH MarimonJunior, E Lenza, AR Marshall, DJ Metcalfe, ETA Mitchard, EF Moran, BW Nelson, R Nilus, EM Nogueira, M Palace, $S$ Patiño, KSH Peh, MT Raventos, JM Reitsma, G Saiz, F Schrodt, B Sonke, HE Taedoumg, S Tan, L White, $\mathrm{H}$ Woll, and J Lloyd. 2011. Height-diameter allometry of tropical forest tress. Biogeosciences. 8:10811106.

Hairiah, K, dan S Rahayu. 2007. Pengukuran Karbon Tersimpan di Berbagai Penggunaan Lahan. World Agroforestry Center-ICRAF. Bogor.

Hairiah, K, A Ekadinata, RR Sari, dan S Rahayu. 2011. Pengukuran Cadangan Karbon dari Tingkat Lahan ke Bentang Lahan. Ed. Ke-2. World Agroforestry Centre-ICRAF. Bogor.

Istomo, dan NE Farida. 2017. Potensi simpanan karbon di atas permukaan tanah tegakan Acacia nilotica L. (Willd) ex. Del. di Taman
Nasional Baluran, Jawa Timur. Pengelolaan Sumberdaya Alam dan Lingkungan. 7(2): 155162.

Khairani, KI. 2019. Pengaruh Lereng terhadap Karakteristik Tanah, Pertumbuhan dan Kadar Hara Daun Tanaman Jati (Tectona grandis L.f) di Sukamakmur, Kabupaten Bogor. [Skripsi]. IPB University. Bogor.

Mawazin, dan H Suhendi. 2008. Pengaruh jarak tanam terhadap pertumbuhan diameter Shorea parvifolia Dyer. Penelitian Hutan dan Konservasi Alam. 5(4): 381-388.

Miyakuni, K, NM Heriyanto, I Heriansyah, R Imanuddin, dan Y Kiyono. 2005. Allometric equations and parameters for estimating the biomass of planted Pinus merkusii Jungh. Et de Vr. forests. Japanese Journal of Forest Environment. 47(2): 95-104.

Pebriandi, E Sribudiani, dan Mukhamadun. 2013. Estimation of the carbon potential in the above ground at the stand level poles and trees in sentajo protected forest. JOM Faperta. 1(1): 1-13.

Purwanto, RH, Rohman, A Maryudi, T Yuwono, DB Permadi, dan M Sanjaya. 2012. Potensi biomasa dan simpanan karbon jenis-jenis tanaman berkayu di hutan rakyat Desa Nglanggeran, Gunungkidul, Daerah Istimewa Yogyakarta. Jurnal Ilmu Kehutanan. 6(2): 128-141.

Rahajoe, JS, dan L Alhamd. 2013. Biomassa gugur serasah dan variasi musiman di Hutan Dataran Rendah TN. Gunung Gede Pangrango. Biologi Indonesia. 9(1): 101-109.

Refliaty, dan EJ Marpaung. 2010. Kemantapan agregat ultisol pada beberapa penggunaan lahan dan kemiringan lereng. Hidrolitasn 1(2): 35-42.

Riyanto, Indriyanto, dan A Bintoro. 2013. Produksi serasah pada tegakan hutan di blok penelitian dan pendidikan Taman Hutan Raya Wan Abdul Rachman Provinsi Lampung. Sylva Lestari. 1(1): 1-8.

Rositah, R Herawatiningsih, dan G Hardiansyah. 2013. Pendugaan biomassa karbon serasah dan tanah pada hutan tanaman (Shorea leprosula) system TPTII PT. Suka Jaya Makmur. Hutan Lestari. 1(3): 358-366.

Sallata, MK. 2013. Pinus (Pinus merkusii Jungh et de Vriese) dan keberadaannya di Kabupaten Tana Toraja, Sulawesi Selatan. Info Teknis EBONI. 10(2): 85-98. 
Sandrawati, A, A Setiawan, dan G Kesumah. 2016. Pengaruh kelas kemiringan lereng dan penggunaan lahan terhadap sifat fisik tanah di Kawasan Penyangga Waduk Cirata Kecamatan Cipeundeuy Kabupaten Bandung Barat. Soilrens. 14(1): 6-10.

Scheyvens, H, EI Gene, and M Yamanoshita. 2011. Community Carbon Accounting Action Research Project. Institute for Global Environment Strategies/IGES. Available online at https://www.iges.or.jp/en/pub/communitycarbon-accounting-action-research-0/en. Accessed July 2021.

Suryanto, dan Wawan. 2017. Pengaruh kemiringan lahan dan Mucuna bracteate terhadap aliran permukaan dan erosi di PT Perkebunan Nusantara V Kebun Lubuk Dalam. JOM Faperta. 4(1): 1-15. 